\title{
Średniowieczne wierzenia - nieczysta siła w kulturze Słowian
}

Wierzenia Słowian sprzed etapu chrześcijańskiego wiążą się ściśle z pogaństwem. Ta politeistyczna religia Słowian była częścią ogromnego kompleksu przekazywanych z pokolenia na pokolenie pierwotnych wierzeń, tradycji, obrzędów, rytuałów. Wśród ludzi panowało przekonanie, że w ich życiu stale obecne są siły nadprzyrodzone. Takie poglądy i wierzenia stworzyły system mitologiczny tłumaczący miejsce człowieka w świecie oraz jego relacje z bóstwami.

Przeprowadzenie szczegółowej analizy i charakterystyki wierzeń Słowian stanowi nie lada wyzwanie. Mimo że mitologie pogańskie przetrwały, w społeczeństwie były one przekazywane ustnie z pokolenia na pokolenie, a pojawienie się chrześcijaństwa w znacznym stopniu zmieniło ich pierwotną formę. Natomiast oralny charakter takich przekazów sprawia, iż są one przez naukę sklasyfikowane jako kultura mniej wartościowa od piśmiennej. Ponadto, jak zauważył w swojej książce Słowiańska Ruś, pogaństwo i kobiety Aldo C. Marturano, na ziemiach ruskich od najdawniejszych czasów mieszały się ze sobą kultury Słowian i innych ludów (w tym Ugrofinów), przez co trudno postawić wyraźną granicę, oddzielić jedną mitologię od drugiej ${ }^{1}$.

Niewątpliwie pogaństwo miało ogromny wpływ na formowanie świadomości ludzi. Ogarnęło zarówno kulturę duchową, jak i materialną. Społeczeństwo dysponujące niezbyt obszerną (w porównaniu z dzisiejszymi osiągnięciami nauki) wiedzą, dotyczącą otaczającego świata, próbowało znajdować wyjaśnienia, oswajać niewytłumaczalne wówczas zjawiska. W rozumieniu pewnych faktów pomagała rozwinięta demonologia, będąca częścią mitologii, dotyczącą postaci mitologicznych niższego rzędu. Kazimierz Moszyński pod szeroko pojętym hasłem „demony” rozumie „wszystkie prócz bóstw mityczne istoty człekokształtne (wyjątkowo też zoomorficzne, lecz w takim wypadku wyraźnie wywodzące się od duszy człowieka i ukazujące się m.in. w ludzkiej lub częściowo ludzkiej postaci)”2.

\footnotetext{
A. C. Marturano, Słowiańska Ruś, pogaństwo i kobiety, Szczecin 2011.

2 K. Moszyński, Kultura ludowa Słowian, cz. II: Kultura duchowa, z. 2, Kraków 1939, s. 604 .
} 
Rzeczy, których nie jesteśmy w stanie przewidzieć lub takie, nad którymi nie mamy kontroli, deprymują nas i przerażają po dziś dzień. W czasach średniowiecznych, bez wątpienia, więcej było niezrozumiałych, straszliwych zjawisk, którym Słowianie musieli stawiać czoła. Trudno było uznać i zrozumieć fakt, że natura jest kapryśna i czasem płata człowiekowi figle. Szalejące żywioły, epidemie, łatwiej było identyfikować z nieczystą siłą. Różnego typu anomalie przypisywano wówczas działaniom niewidzialnych czy też trudnych do zidentyfikowania i rozpoznania stworzeń.

Słowiańska przestrzeń mitologiczna składała się z dwóch równolegle istniejących światów - „swojego” oraz „obcego”. Swój - jako uporządkowany, stworzony przez bogów kosmos, stanowił przestrzeń życia, natomiast obcy - jako nieskończony chaos, jawił się ludzkiej wyobraźni niczym przestrzeń przebywania istot demonicznych ${ }^{3}$.

$\mathrm{Z}$ demonologią u Słowian wschodnich wiązało się pojęcie nieczystej siły. Oznaczała ona ogólny zbiór postaci mitologicznych niższego rzędu (demonów, duchów), przynależących do „obcego”, „tamtego” świata. Tajemne siły mogły bowiem pomagać, bądź przeszkadzać człowiekowi. Zdarzało się również, że wnikały w niego, wywołując ból, choroby, koszmary.

Nieczystą siłę bardzo często personifikowano, nadając jej cechy ludzkie. $\mathrm{W}$ wierzeniach Słowian powstał cały zbiór cech wyglądu przypisywanych postaciom demonicznym. A i sami ludzie odbiegający wyglądem od przyjętej społecznie normy, postrzegani byli jako istoty obdarzone tajemnymi mocami lub powiązane z siłą nieczystą:

Wszelkie anormalności, uzewnętrzniające się w wyglądzie ciała ludzkiego, nawet drobne [...] zwracają na siebie uwagę ludu i podniecają grę wyobraźni, dając początek demonograficznym motywom ${ }^{4}$.

Barwa ciała ciemniejsza od tradycyjnego koloru skóry, nadmierne owłosienie, gęste brwi, zrośnięte nad nosem lub całkowity ich brak - to tylko niektóre z wielu cech wyglądu, wywołujących skojarzenia ze światem magicznym. Postaci, uznawane za demoniczne charakteryzował często niezwykle wysoki bądź też karłowaty wzrost oraz wielka głowa. Istotne w wyglądzie były również oczy. Ich nienaturalną wielkość czy też czerwoną barwę także przypisywano demonom. Za kolejną cechę, charakteryzującą na Rusi demony wiatru, uznawano wielkie lub grube wargi. Natomiast demony wodne

3 U. Wójcicka, Из истории русской культуры. Языческое наследие в традииионной культуре, Bydgoszcz 2002, s. 20.

4 K. Moszyński, Kultura ludowa Słowian..., s. 613. 
(najczęściej Rusałki) miały długie włosy, często koloru zielonego. Czarty zaś u Słowian (nie tylko wschodnich) często bywały kulawe. Poza uosabianiem nieczystej siły, obdarzano ją również cechami zoomorficznymi lub wyobrażano sobie jako postaci na poły ludzkie i zwierzęce.

Bardzo popularnym motywem było posiadanie zwierzęcych nóg lub ogona ${ }^{5}$.

Słowianie bardzo często oskarżają czarownice o posiadanie ogona, zwłaszcza o ile chodzi o wiedźmę z urodzenia, a nie taką, co się wiedźmiarstwa nauczyła u innej. Ciekawe, że Wielkorusi kaukascy posądzają nawet swych wróżbitów o posiadanie wspomnianej cechy; w niektórych znów okolicach Rusi południowo-zachodniej przypisują ogon ludziom, którzy po śmierci mają się stać upiorami. Najpospoliciej jednak słyszymy o ogonach u czartów ${ }^{6}$.

Pogańska wiara w istnienie nieczystej siły oraz zamieszkujące przyrodę i nieprzerwanie wpływające na życie człowieka istoty, nie zniknęła wraz z nadejściem epoki chrześcijaństwa. Była tak silnie zakorzeniona w świadomości ludzi i przekazywana z pokolenia na pokolenie, że funkcjonowała jeszcze przez długi czas. Takie równoczesne funkcjonowanie wierzeń pogańskich z nową chrześcijańską religią nosiło nazwę двоеверие ${ }^{7}$. W dzisiejszym świecie znajdujemy również elementy dawnych wierzeń naszych przodków (np. równoczesne umieszczanie medalików $\mathrm{z}$ wizerunkami świętych i czerwonych tasiemek przy kołysce noworodka).

Geneza nieczystej siły jest niejednoznaczna. Istnieje kilka teorii dotyczących pojawienia się demonicznych postaci. Wśród Słowian podstawę demonologicznych wierzeń stanowiły wyobrażenia nieczystej siły, wskazujące, że pochodzi ona od zmarłych. Ze śmiercią w kulturze Słowian łączył się również kult przodków. Rozróżniano dwa rodzaje zmarłych: ci, których dusze znalazły uspokojenie na „tamtym świecie” i ci, których dusze kontynuowały swoje pośmiertne istnienie "na granicy” dwóch światów. Do pierwszej grupy zaliczano tych, którzy umarli „prawidłową”, naturalną śmiercią i pochowani zostali zgodnie z rytualnymi zasadami (tzw. родители ${ }^{8}$ ). Tacy zmarli przodkowie stawali się opiekunami swoich potomków. Do nich modlono

5 Cechy wyglądu zewnętrznego istot demonicznych na podstawie K. Moszyński, Kultura ludowa Słowian..., s. 604-717; P. Zych, W. Vargas, Bestiariusz słowiański. Rzecz o skrzatach, wodnikach i rusałkach, Olszanica 2014.

$6 \quad$ K. Moszyński, Kultura ludowa Słowian..., s. 627.

7 Двоеверие (dvoeverie) - termin oznaczający dwuwiarę.

8 Родители (roditeli) - termin oznaczający rodziców. 
się o opiekę nad domem, zdrowie członków rodziny, bydła, o urodzaj itp. Wierzono, że nawet po śmierci przodkowie kontynuują swoje współegzystowanie z potomkami. Drugą grupę tworzyli tzw. nieczyści zmarli. Ludzie, którzy zakończyli żywot w nienaturalny sposób (np. poprzez uduszenie, utopienie, samobójstwo itd.) stawali się „złymi” nieboszczykami, ponieważ nie wykorzystali w pełni danej im życiowej siły. Mogli oni zaszkodzić żywym na różne sposoby. Według podań ludowych, mianem nieczystych określano trzy typy zmarłych. Pierwszy z nich, tzw. заложные ną, przedwczesną, gwałtowną śmiercią, pochowani z naruszeniem rytuału lub w ogóle niepogrzebani. Drugi - ходячие ${ }^{10}$, czyli ci, którzy nie zerwali swoich więzi z życiem, nie otrzymawszy swojej „doli”, np. chrztu i imienia, współmałżonka, odpuszczenia grzechów, rytualnych pogrzebin itd. Trzeci typ nieczystych zmarłych to tzw. двоедушники $u^{11}$ - ci, którzy za życia pozostawali w kontakcie z nieczystą siłą (np. mieli dar jasnowidzenia) ${ }^{12}$.

Słowiańsko-ruskie pogaństwo przedstawiało zmarłych jako przedmiot zainteresowania nieczystej siły, która mogła przemienić ich np. w wampiry, dlatego też ciała po śmierci należało niezwłocznie unicestwić - „oddać” Matce Ziemi bądź spalić. Panowało przekonanie, że zmarli posiadają władzę nad żywymi. Aby uniknąć grożącego niebezpieczeństwa, odnoszono się z szacunkiem do zmarłych przodków, zwracano się do nich z prośbami. Próbowano ułaskawić ich rytualnym karmieniem, symbolicznie zapraszając umarłych na wieczerzę z okazji świąt.

Łączenie pochodzenia nieczystej siły ze śmiercią było jedną z bardziej popularnych, choć nie jedyną, funkcjonującą teorią. W społeczeństwie istniało również przekonanie, jakoby pochodziła ona od upadłych aniołów, wygnanych $\mathrm{z}$ nieba razem $\mathrm{z}$ szatanem po buncie przeciw Bogu. W miejscu, w którym spadły, osiedlały się, zmieniając $\mathrm{w}$ istoty demoniczne. Inna teoria głosi, że demony wylęgały się z niezwykłego jaja kurzego ${ }^{13}$. Folklor słowiański przepełniony jest podobnymi historiami, wyjaśniającymi powstanie nieczystego.

Przestrzeń mitologiczną w czasach dawnej Rusi przedstawiano za pomocą osi wertykalnej w formie drzewa. Korona symbolizowała niebo, pień - ziemię, a korzenie - „tamten” świat. Jeśli zaś drzewo przedstawione było

\footnotetext{
9 Заложные (zalozhnye) - odpowiednik polski: nawie.

10 Ходячие (hodiachie) - chodzący (zmarli).

11 Двоедушники (dvoedushniki) - posiadający dwie dusze.

12 U. Wójcicka, Из истории русской культуры..., s. 48.

13 K. Moszyński, Kultura ludowa Słowian..., s. 604-717.
} 
odwrotnie, koroną w dół, oznaczało oś świata pozagrobowego, który uważany był za lustrzane odbicie tego ziemskiego. W takim pojmowaniu organizacji przestrzeni niezwykle ważną rolę pełniły rzeki. Były one symbolicznie uważane za system krwionośny „ciała” ziemi. Ich funkcję stanowiło łączenie dwóch światów. Wierzono również, że martwi płynęli do życia pośmiertnego właśnie rzeką lub też, że przedostawali się tam przez most na niej, który miał być cieńszy od włosa. Taka rzeka, po której przeprawiali się umarli na „drugą stronę" nosiła nazwę 3абыть-река ${ }^{14}$ (забыть - zapomnieć, река rzeka). Po takiej przeprawie nieboszczyk zapominał o swoim ziemskim życiu i stawał się pełnoprawnym obywatelem królestwa umarłych ${ }^{15}$.

Miejsca pojawiania się tajemnych sił były prawie niemożliwe do określenia. Wedle przekonań, postaci demoniczne stanowiły część natury. Nieczysta siła mogła się pojawiać praktycznie wszędzie. Jednak niektóre miejsca upodobała sobie szczególnie. Były to z reguły miejsca tajemnicze, niepoznane przez człowieka, tj. głębokie otchłanie zbiorników wodnych, jamy, pieczary, bagna, studnie. $\mathrm{Z}$ racji powiązania ze zmarłymi częstym obszarem związanym z demonami był cmentarz, ale również i bania (rosyjska łaźnia), ponieważ wchodząc do niej ludzie pozbawiali się odzieży oraz wszelkich ochronnych amuletów. Ponadto idealne miejsce dla nieczystej siły stanowiły miejsca związane z szeroko pojętą granicą, np. progi, rozstaje dróg, skrzyżowania, mosty, granice wsi, pól. Granica w dawnej Rusi kojarzyła się z niebezpieczeństwem, oddzielała świat żywych od świata umarłych, czyste od nieczystego. W związku z tym,

[...] dom, jako bezpieczna przestrzeń zamknięta posiadał kilka otworów, przez które mogła zostać naruszona jego czystość: drzwi (próg), okna, komin pieca. Próg [...] chroniony był za pomocą zamka, symboli ochronnych, rytualnych zakazów. Nie wolno było siadać ani stawać na progu, witać się przez próg, Pannie Młodej nie wypadało dotykać progu (dlatego też przenosił ją Pan Młody na rękach), itd. Okno także wypełniało rolę granicy, mogło ono zamienić drzwi, aby oszukać nieczystą siłę czy śmierć [...]. Komin pieca - otwór związany z latającą nieczystą siłą: ognistym żmijem, czartami, wiedźmami. Przez niego, według wierzeń, przenikają do domu choroby, „dola”, itd. Podczas burzy komin powinien być zamknięty, inaczej wleci tam nieczysta siła a piorun uderzy w dom ${ }^{16}$.

14 Забыть-река (zabyt'-reka) - rzeka zapomnienia.

15 Л. А. Чёрная, История культуры Древней Руси, Москва 2011, s. 42.

16 Ibidem, s. 43 (tłumaczenie własne - M.N.). 
Bardzo często miejsce występowania wpływało na nazwę, nadawaną spersonifikowanej tajemnej sile. Banię zamieszkiwał Банник ${ }^{17}$, w lasach czaił

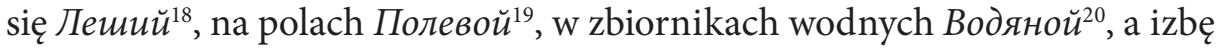
poza domownikami zamieszkiwał również Домовой ${ }^{21}$. Nie jest to, rzecz jasna, jedyna etymologia nazw demonicznych postaci. Lista nazw pogańskich „straszydeł” była długa i bardzo rozbudowana. Nazwy poszczególnych demonów ulegały również różnorodnym wariacjom w zależności od regionu. $\mathrm{Na}$ przykład, demona domowego wschodni Słowianie nazywali najpowszechniej „domowym”; bardzo pospolicie też - „dziadem”, „dziadkiem” lub „domowym dziadem”, poza tym jednak tytułowali go także „gospodarzem”, "sąsiadem" i „karmicielem"22.

Wszystko, co działo się w życiu człowieka lub w jego otoczeniu i nie dawało się w racjonalny sposób wytłumaczyć, przypisywano działaniu siły nieczystej. To ona powodowała bezsenność, „dusiła” we śnie, zsyłała choroby, kusiła do złych czynów, samobójstwa, męczyła zwierzęta, była sprawcą nieporządku w izbie, zbijała z tropu podróżnych, sprawiając, że gubili drogę itd. Należało być ostrożnym, aby nie narazić się tajemnym siłom i nie sprowadzić nieszczęścia na rodzinę, domostwo, pole, czy zgromadzone zapasy. Wierzono również, że należy z szacunkiem podejmować przybyłych gości (znajomych czy też nie), ponieważ mogli oni być wcieleniem zmarłych przodków bądź złych mocy. Uważano bowiem, że gość był posłańcem losu i konieczne było przyjęcie go. Jednak sposób, w jaki przebiegała ta wizyta mógł mieć wpływ na życie gospodarzy, brak należytego szacunku mógł skutkować zemstą tajemniczej siły.

Strach powstrzymywał ludzi przed odwiedzaniem niebezpiecznych miejsc oraz prowadzeniem działań w czasie, uważanym za nieczysty (związanym $\mathrm{z}$ granicą), np. wystrzegano się wychodzenia z domu o północy. Wierzono również, że przez wszystkie otwory w ciele człowieka mogła wniknąć w niego moc nieczysta. Aby ustrzec się jej, Słowianie opracowali szereg rytuałów, znaków, zdobień, mających spełniać funkcje apotropaiczne. Symbole ochronne, odstraszające zło, umieszczane na odzieży, przedmiotach codziennego użyt$\mathrm{ku}$, zabudowaniach nosiły wspólną nazwę oбepezu ${ }^{23}$ i służyły zapewnieniu

17 Банник (bannik) - duch, zamieszkujący banię (łaźnię).

18 Леший (leshij) - duch, zamieszkujący lasy (leszy).

19 Полевой (polevoj) - duch, zamieszkujący pola.

20 Водяной (vodianoj) - duch, zamieszkujący zbiorniki wodne.

21 Домовой (domovoj) - duch domowy.

22 K. Moszyński, Kultura ludowa Słowian..., s. 670.

23 Оберегu (oberegi) - słowo oznaczające amulety oraz inne symbole i znaki ochraniające. 
bezpieczeństwa oraz opieki bogów. Jednak zdarzało się czasem, że ludzie świadomie wstępowali w kontakty z nieczystym, np. poprzez wróżby, aby odgadnąć przyszłość czy poznać swój dalszy los. W celu dobrowolnego obcowania z tajemnymi siłami zdejmowano atrybuty chrześcijańskie lub pogańskie оберегu i udawano się w miejsca, uważane za siedliska zła, tj. skrzyżowanie czy bania, aby tam oddawać się tajemnym praktykom.

Podsumowując niniejsze rozważania, należy podkreślić wagę wierzeń w czasach średniowiecznych. W okresie, kiedy nauka nie była nazbyt rozwinięta, do opisywania organizacji świata i rzeczywistości człowieka nie używano logicznych i racjonalnych argumentów, ale postrzegano je przez pryzmat mitologii. To właśnie ona służyła do tłumaczenia niewytłumaczalnego. Pogańskie wierzenia obecne były na każdym etapie życia Słowian i w każdej jego sferze. Dziś spuścizna naszych dalekich przodków ma walory artystyczne, obecna jest w elementach kultury czy literaturze, jednak jej pozostałości w codziennym życiu kategoryzowane są już jako „zabobony”.

\section{Bibliografia}

BRÜCKNER A., Mitologia słowiańska i polska, Warszawa 1985.

чЁРНАЯ Л. А., Антропологический код древнерусской культуры, Москва 2008.

ЧЁРНАЯ Л. А., История культуры Древней Руси, Москва 2011.

GIEYSZTOR A., Mitologia Stowian, Warszawa 2006.

МАКСИМОВ С. В., Нечистая, неведомая и крестная сила, Санкт-Петербург 1994.

MARTURANO A. C., Słowiańska Ruś, pogaństwo i kobiety, Szczecin 2011.

MOSZYŃSKI K., Kultura ludowa Słowian, cz. II, z. 1-2, Kraków 1934.

РОМАНОВ Б., Люди и нравы Древней Руси, Москва 2014.

WÓJCICKA U., Из истории русской культуры. Языческое наследие в традииионной культуре, Bydgoszcz 2002.

ZYCH P., VARGAS W., Bestiariusz słowiański. Rzecz o skrzatach, wodnikach, rusałkach, Olesznica 2014. 